\title{
Soft Soil Retrofitting Study with Bamboo Concave Mattress Against Stability of Jombang - Kertosono Railway Double Track Slope Due to Earthquake Load
}

\author{
Suprayitno $^{1 *}$, Helmy Darjanto ${ }^{2}$ \\ Narotama University, Surabaya, \\ suprayitno23@gmail.com
}

\begin{abstract}
Soft soil in construction work is a problem. This is due to the low carrying capacity of the land. Low carrying capacity can cause losses, ranging from losses in terms of construction costs that are increasingly expensive, to the threat of construction safety, ie structures that are made unable to stand stably. The stability of the soft soil found in the location of the railway double track planning can be improved by the method of bamboo slab mattress because the carrying capacity of the soil increases due to pressure from the bamboo slabs that enter the soil. In this study bamboo slabs were used in order to strengthen the stability of embankments on the double track railroad where the embankment did not experience the collapse of the load of the pile itself or due to the burden of the passing train. The earthquake load can affect the stability of the slope of the double track railroad, this is evidenced from the analysis using the plaids program so that the internal force can be known. In the writing of this study, we will draw a picture of soft soil reinforcement modeling with bamboo slabs, which analyzes the calculations with additional earthquake loads. This can be a reference in the implementation of the construction of railroad lines in Indonesia, which are located in vulnerable locations with wetland conditions or rice fields.
\end{abstract}

Keywords: Soft Soil, Heap, Double Track

\section{INTRODUCTION}

The structure of the street railway was a construction which was planned as infrastructure infrastructure and train ride. The concept of the structure of the railway superstructure is a series of roads and structures into a unified interconnected to accept and support the movement of the train safely (Rosyidi, 2015). In the writing of this thesis will memberihkan overview of modeling in soft soil reinforcement purposes with bamboo cerucuk mats, which performed the analysis of the calculation with the additional burden of the earthquake. This can be a reference in the implementation of the construction companies-railroad line in Indonesia found in locations prone to condition the soil berawah or rice fields.

\section{REVIEW AND LITERATURE}

The wearing of cerucuk intended to enhance soil shear tanahan on location done study. If the ground resistance against the shear increased, power support the increase. Construction of cerucuk that can be used i.e., bamboo cerucuk, cerucuk wood, cerucuk concrete (micropile) and others. usage of cerucuk in soft soil aims to:

1. Enhance support of the land, as a result of installation cerucuk into the soft soil so that soil around the cerucuk become more dense because of the change in part to the volume of land occupied by the pole cerucuk. When a pole inserted into the soil, the land around it to approximately twice the diameter will

Soft Soil Retrofitting Study with Bamboo Concave Mattress Against Stability of Jombang - Kertosono Railway Double Track Slope Due to Earthquake Load

Suprayitno, Helmy Darjanto 
be solidified, Cassagrande (1932).

2. Avoid the onset of sliding, because cerucuk can hold the sliding style bigger than on the ground, in addition cerucuk represented a reinforcement of the amplifier so that it will be able to withstand movement - a movement that occurs on the land

3. Reduce the decline of Foundation construction

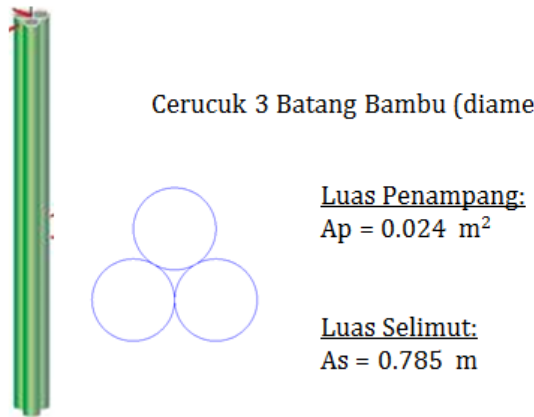

Figure 2.1 Cerucuk Bamboo 1 Group consists of 3 rods of bamboo

Type - the type of bamboo that can be used or recommended for use as a material of bamboo mats and cerucuk is as follows:

1. Bamboo ropes (ginantochloa Apus), bamboo is very tough with a distance of up to $65 \mathrm{~cm}$ and sections with midline 40-80 $\mathrm{mm}$ and the length of the stems reach 6-13 meters.

2. petung Bamboo (Dendrocalamus Asper), bamboo is classified as very strong, with short internode distances, with walls that are thick. Midline bamboo $80-130 \mathrm{~cm}$, length $10-20$ rods $\mathrm{m}$. Bamboo is usually grown at an altitude of $1900 \mathrm{~m}$ above sea level

3. Bamboo Ori/Thorn (Bambusa Blumeana), bamboo is also strong and similar petung bamboo, with short internode distances as well the walls are thick, parts of the outer skin is smoother and slippery compared to bamboo. Bamboo 75-100 mm diameter, stem length 9-18 m.

Cerucuk bamboo mats on the implementation of approaches made to compile/layers, aiming to reduce the burden of a large heap and keeping the grains heap not up

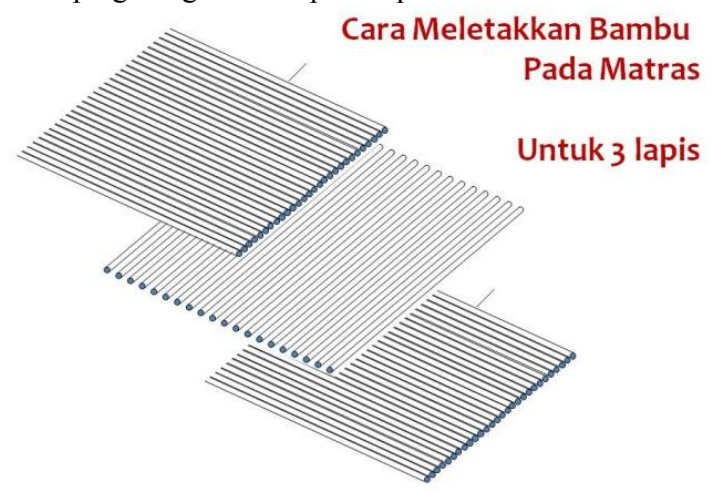

Figure 2.2 model how they saw bamboo cerucuk mats

The wearing of this bamboo cerucuk mats beside less expensive than wear a geotextile in addition is also more environmentally friendly, since many resulting from natural bamboo of indonesia.

1. regular Heap, heap or urugan is used for the achievement of the required elevation end of subgrade in the picture without the intention of other special planning. The usual heap is also used for the replacement of existing subgrade materials that does not qualify. The usual heap of material must meet the following requirements:

- Heap that is classified as an ordinary pile should consist of land approved by the Trustees are eligible

Soft Soil Retrofitting Study with Bamboo Concave Mattress Against Stability of Jombang - Kertosono 
for use in a permanent job.

- the selected Material does not include land that is plastisitasnya high, which is classified as A-7-6 of the requirements of AASHTO M 145 or as $\mathrm{CH}$ in the classification system of "Unified or Casagrande". In addition, this urugan must have the CBR is not less than 6\%, when tested with AASHTO T 193.

- development of high land value is greater than 1.25 active when tested with AASHTO T 258, should not be used as an ingredient of the heap. Active value measured as a comparison between the Plasticity Index (PI) - (AASHTO T 90) and a percentage of the size of the clays (AASHTO T 88).

2. The cover of choice, is a heap or urugan used for the achievement of the required elevation end of subgrade in images for the purpose of planning and other special, for example, to reduce a thick layer of Foundation of bottom, to minimize style the lateral soil pressures behind retaining walls talud road. Material heap options must meet the following requirements:

- Heap can only be classified as "a heap of options" when used on the site or for the purpose for which it has been determined or approved in writing by the Supervisor.

- Heap that is classified as a heap of options should consist of sandy soil (sandy clay) or padas are compliant and in addition must have certain traits depending on the intention of its use. In all, the entire urugan option must have a CBR of at least $10 \%$, when tested in accordance with AASHTO T 193

\section{Rail Road Construction}

Cross the railway planned to miss a wide number of transport of goods and/or passengers in a given period of time. Planning a rail road construction must be planned in such a way that it can be technically and economically justified. Technically refers to a road construction the rail must be crossed by a rail vehicle safely with a certain level of comfort during the age of construction. In eknomis it is expected that the construction and maintenance of the construction can be organized at a cost that is as small as possible which still allow provided security and comfort level. Rail road construction planning diperngaruhi by the amount of load, the maximum speed, axle load and patterns of operation. It was held on the basis of the classification of rail roads, so that planning can be made are appropriate.

\section{The speed and Axle Load}

a. speed.

1) speed plan.

The speed of the plan is the speed used to plan construction of rail roads.

a) for planning rail road structure.

b) For planning of exaltation

$$
\mathrm{V} \text { plan }=1.25 \times \mathrm{V} \text { Max. }
$$$$
V \text { rencana }=c x \frac{\sum N i \cdot V i}{\sum N i}
$$

$\mathrm{c}=1.25$

$\mathrm{NI}=$ number of the passing train.

$$
\mathrm{Vi}=\text { Operating Speed }
$$

c) for planning the radius of curvature of the circle and curved the transition

$$
\text { Vrencana }=\text { Vmaks }
$$

2) maximum speed

Maximum speed is the highest speed permitted for the operation of trains on a series of specific traffic.

3) operating speed

Operating speed is the average speed of trains on a certain swath of streets.

4) Commercial Speed

Commercial speed is the average speed of trains as a result of the Division of mileage with travel time.

\section{b. Axle Load.}

Axle load is a load which is accepted by the road of the railway from one axle. For all classes, a maximum axle load is 18 tons.

\section{Rail Road Standard.}

Soft Soil Retrofitting Study with Bamboo Concave Mattress Against Stability of Jombang - Kertosono Railway Double Track Slope Due to Earthquake Load

Suprayitno, Helmy Darjanto 
a. classification.

Haulage speed maximum speed, axle load and other provisions for any class path, are listed on the table

Table 2.1. Class Road Rail

\begin{tabular}{|c|c|c|c|c|c|c|c|c|}
\hline $\begin{array}{c}\text { Klasifik } \\
\text { asi Jalan } \\
\text { KA }\end{array}$ & $\begin{array}{c}\text { Pasing } \\
\text { Ton } \\
\text { Tahunan } \\
\text { (Juta Ton) }\end{array}$ & $\begin{array}{c}\text { Perencanaan } \\
\text { Kecepatan KA } \\
\text { Maksimum } \\
\mathrm{V}_{\max }(\mathrm{km} / \mathrm{jam})\end{array}$ & $\begin{array}{c}\text { Tekanan } \\
\text { Gandar } \\
\text { P max } \\
\text { (ton) }\end{array}$ & Tipe Rel & $\frac{\text { Tipe dari Bantalan }}{\text { Jarak Bantalan }(\mathrm{mm})}$ & $\begin{array}{c}\text { Tipe } \\
\text { Alat } \\
\text { Penam } \\
\text { bat } \\
\end{array}$ & $\begin{array}{c}\text { Tebal balas } \\
\text { dibawah } \\
\text { Bantalan } \\
(\mathrm{cm})\end{array}$ & $\begin{array}{l}\text { Lebar } \\
\text { Bahu } \\
\text { Balas } \\
(\mathrm{cm}) \\
\end{array}$ \\
\hline 1 & $>20$ & 120 & 18 & $\mathrm{R} 60 / \mathrm{R} 54$ & $\frac{\text { Beton }}{600}$ & EG & 30 & 50 \\
\hline 2 & $10-20$ & 110 & 18 & R54 / R50 & $\frac{\text { Beton/Kayu }}{600}$ & EG & 30 & 50 \\
\hline 3 & $5-10$ & 100 & 18 & R54/R50/R42 & $\frac{\text { Beton/Kayu/Baja }}{600}$ & EG & 30 & 40 \\
\hline 4 & $2,5-5$ & 90 & 18 & R54/R50/ R42 & $\frac{\text { Beton/Kayu/Baja }}{600}$ & $\mathrm{EG} / \mathrm{ET}$ & 25 & 40 \\
\hline 4 & $<2,5$ & 80 & 18 & R42 & $\frac{\text { Kayu/Baja }}{600}$ & ET & 25 & 35 \\
\hline
\end{tabular}

ET $=$ Single Rubbery; EG $=$ Double Elastic

\section{DATA AND METHODOLOGY}

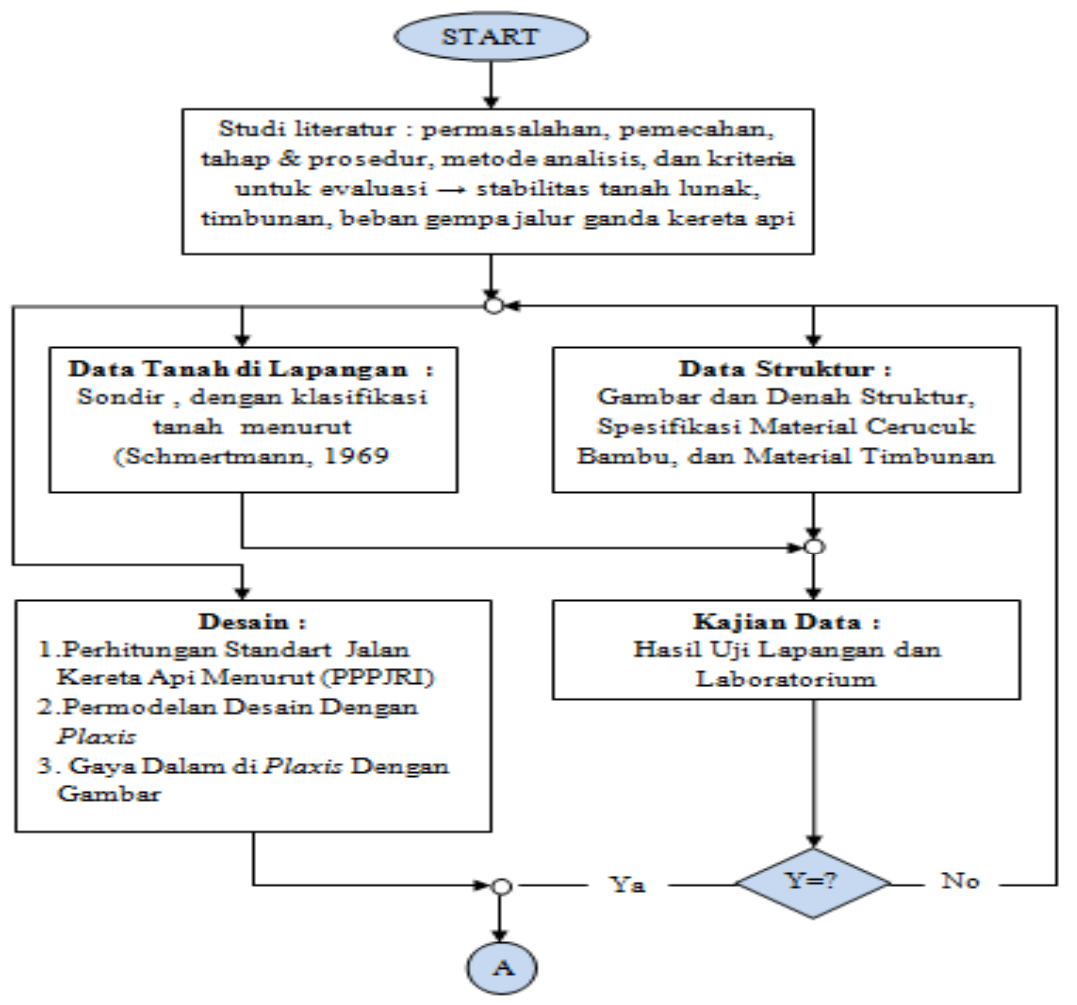

Soft Soil Retrofitting Study with Bamboo Concave Mattress Against Stability of Jombang - Kertosono Railway Double Track Slope Due to Earthquake Load Suprayitno, Helmy Darjanto 


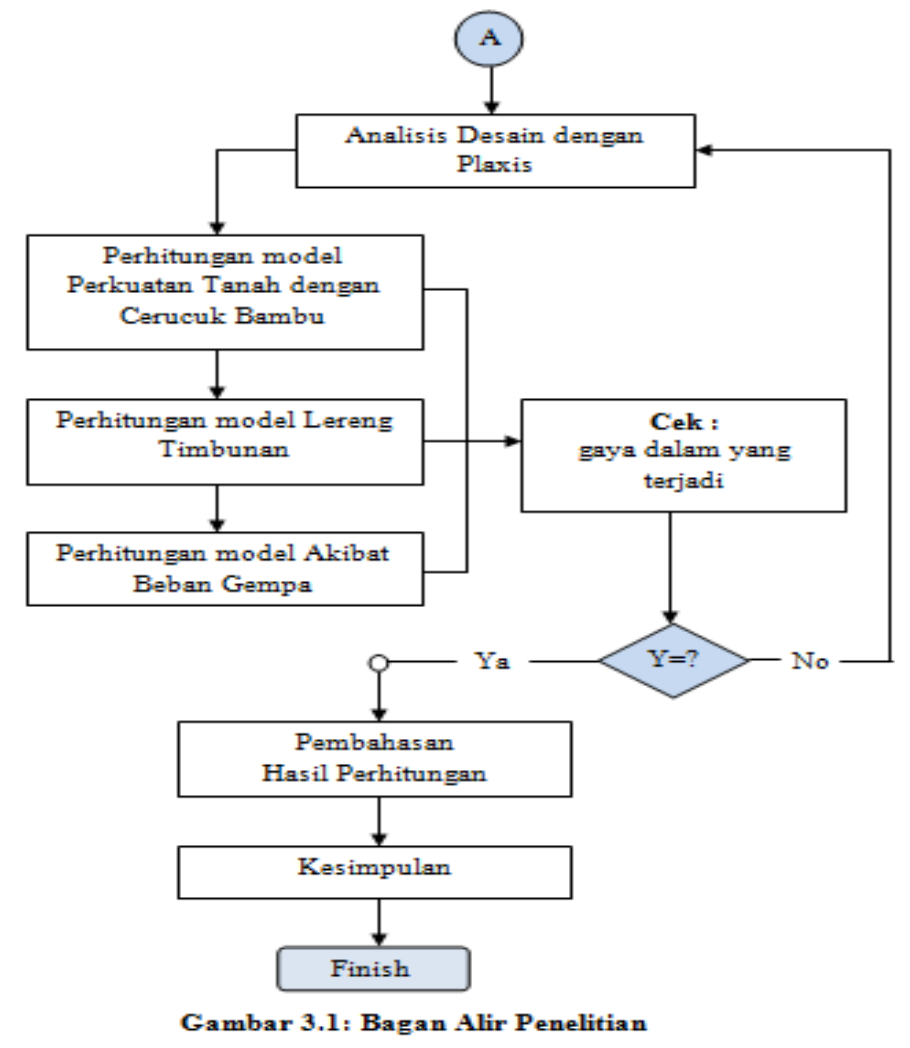

\section{ANALYSIS AND DISCUSSION}

In the method implementation construction soft soil improvements need to be made, the method used is by installing a pile of bamboo as follows:

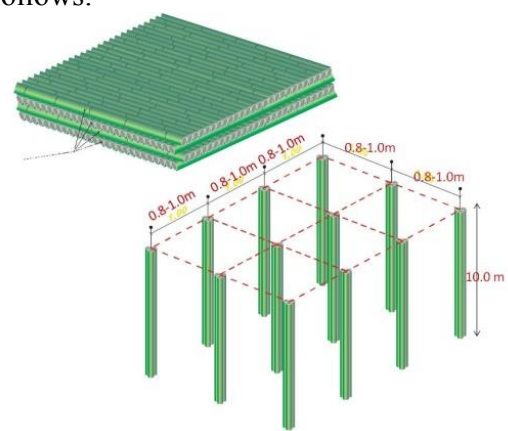

Figure 4.1 group pile of bamboo

After the pile installed then retaining pile foundation is done by installing a bamboo cerucuk mats with the following model:

Soft Soil Retrofitting Study with Bamboo Concave Mattress Against Stability of Jombang - Kertosono Railway Double Track Slope Due to Earthquake Load Suprayitno, Helmy Darjanto 


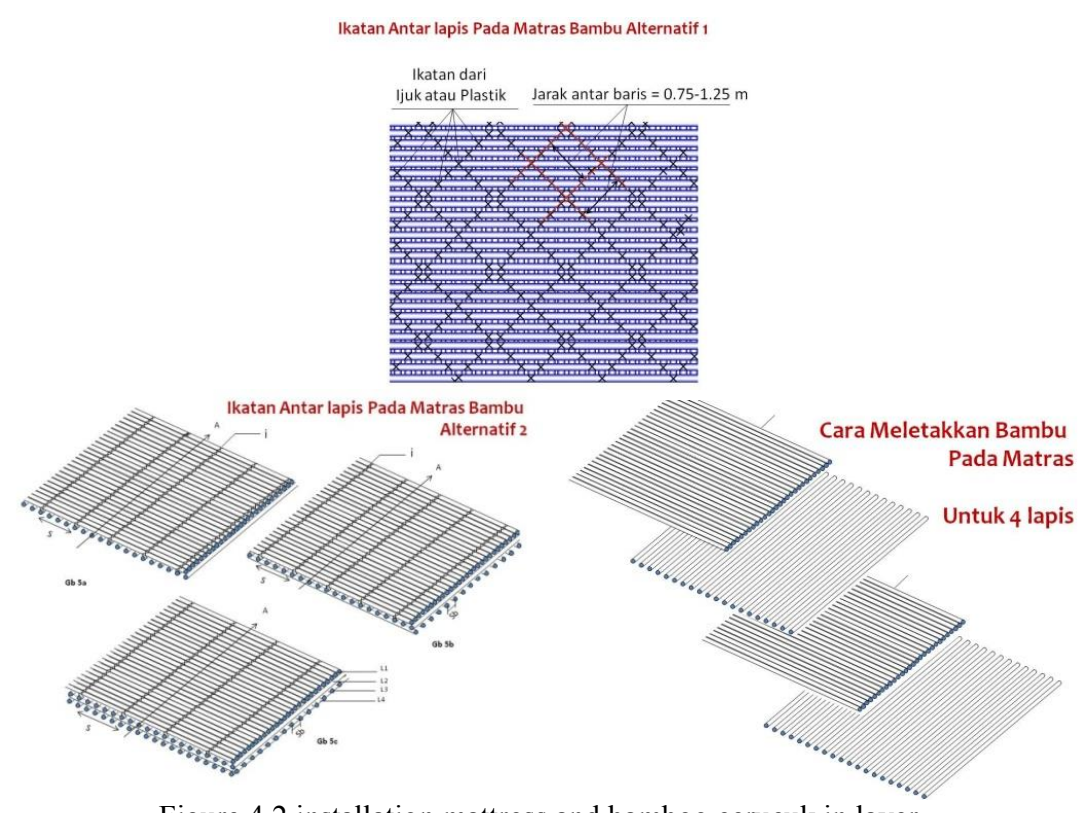

Figure 4.2 installation mattress and bamboo cerucuk in layer

Then the modeling was done in accordance with the design of the planned program Plaxis 2D.

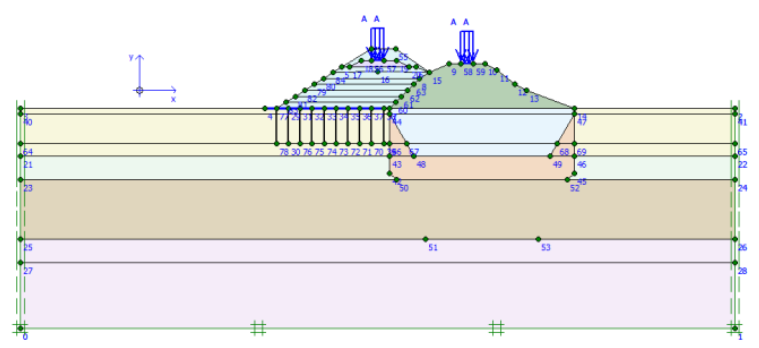

Figure 4.3 Plaxis 2D cross section Model km106 + 150

The calculations are performed in the styles to find out critical areas/SF and analysis behind the failure also made the fix. Data in-put the calculation parameters are obtained from the original soil materials provide from data sondir like the following table

Table 4.1 Material Parameters of soils

\begin{tabular}{|l|c|c|c|c|c|c|c|}
\hline Lapisan Tanah & $\begin{array}{c}\text { Yd } \\
\mathbf{( k N / m 3 )}\end{array}$ & $\begin{array}{c}\text { Ysat } \\
\mathbf{( k N / m 3 )}\end{array}$ & $\begin{array}{c}\mathbf{c u} \\
\mathbf{( k N / m 2 )}\end{array}$ & $\begin{array}{c}\boldsymbol{\phi} \\
\mathbf{(} \boldsymbol{(})\end{array}$ & $\begin{array}{c}\mathbf{E}^{\prime} \\
\mathbf{( k N / m 2 / m )}\end{array}$ & $\mathbf{v}$ & $\mathbf{N}_{\mathbf{S P T}}$ \\
\hline 1-SoftClay & 13 & 15 & 4 & 1 & 800 & 0.35 & - \\
\hline 2-SiltyClay & 14 & 15.5 & 35 & 2 & 9000 & 0.35 & 7 \\
\hline 3-ClayeySand & 16 & 17 & 5 & 15 & 6000 & 0.33 & - \\
\hline 4-SiltyClay & 16.5 & 17.5 & 100 & 5 & 24000 & 0.33 & 20 \\
\hline 5-SandClay & 17 & 17 & 130 & 5 & 40000 & 0.3 & 26 \\
\hline
\end{tabular}

Soft Soil Retrofitting Study with Bamboo Concave Mattress Against Stability of Jombang - Kertosono Railway Double Track Slope Due to Earthquake Load Suprayitno, Helmy Darjanto 
Table 4.2 Parameter Urugan/Heap

\begin{tabular}{|c|c|c|c|c|c|c|c|}
\hline Lapisan & $\begin{array}{c}y d \\
\text { (kN/m3) }\end{array}$ & $\begin{array}{c}\text { Ysat } \\
\text { (kN/m3) }\end{array}$ & $\begin{array}{c}\mathrm{cu} \\
\text { (kN/m2) }\end{array}$ & $\begin{array}{l}\phi \\
\left({ }^{\circ}\right)\end{array}$ & $\begin{array}{c}E^{\prime} \\
(k N / m 2 / m)\end{array}$ & $v$ & NsPT \\
\hline 1-FillSink & 18 & 20 & 20 & 45 & 40000 & 0.3 & 4 \\
\hline 2-Ballas Elastic & 17 & 20 & - & - & 30000 & 0.3 & - \\
\hline 3-Fill-Existing & 17 & 20 & 5 & 45 & 40000 & 0.3 & 9 \\
\hline 4-FillKM106 & 17 & 20 & 5 & 0.3 & 24000 & 0.3 & 1 \\
\hline
\end{tabular}

Table 4.3 Propertis Plate

\begin{tabular}{|l|c|c|c|c|c|c|}
\hline \multicolumn{1}{|c|}{ Lapisan } & Type & EA $(\mathbf{k N} / \mathbf{m})$ & El $(\mathbf{k N m} \mathbf{2} / \mathbf{m})$ & $\boldsymbol{d}(\mathbf{m})$ & $\mathbf{w}(\mathbf{k N} / \mathbf{m} / \mathbf{m})$ & $\mathbf{v}$ \\
\hline 1-Matras 3Lapis & Elastic & $1.41 \mathrm{E}+06$ & $7.95 \mathrm{E}+03$ & 0.26 & 0.94 & 0.3 \\
\hline 2-Matras 4Lapis & Elastic & $1.77 \mathrm{E}+06$ & $2.72 \mathrm{E}+04$ & 0.43 & 1.178 & 0.3 \\
\hline 3-Matras 5Lapis & Elastic & $2.12 \mathrm{E}+06$ & $4.64 \mathrm{E}+04$ & 0.512 & 1.41 & 0.3 \\
\hline
\end{tabular}

Table 4.4 Propertis Anchor

\begin{tabular}{|c|c|c|c|}
\hline Lapisan & Type & EA (kN) & L spacing (m) \\
\hline Bambu (NtN) & $\begin{array}{c}\text { Elasto- } \\
\text { plastic }\end{array}$ & $5.00 \mathrm{E}+03$ & $7.95 \mathrm{E}+03$ \\
\hline
\end{tabular}

Of the data is done in the put value in the plaxis programs and do a model of runing already made, then retrieved the data results of the analysis are presented in the following figure:

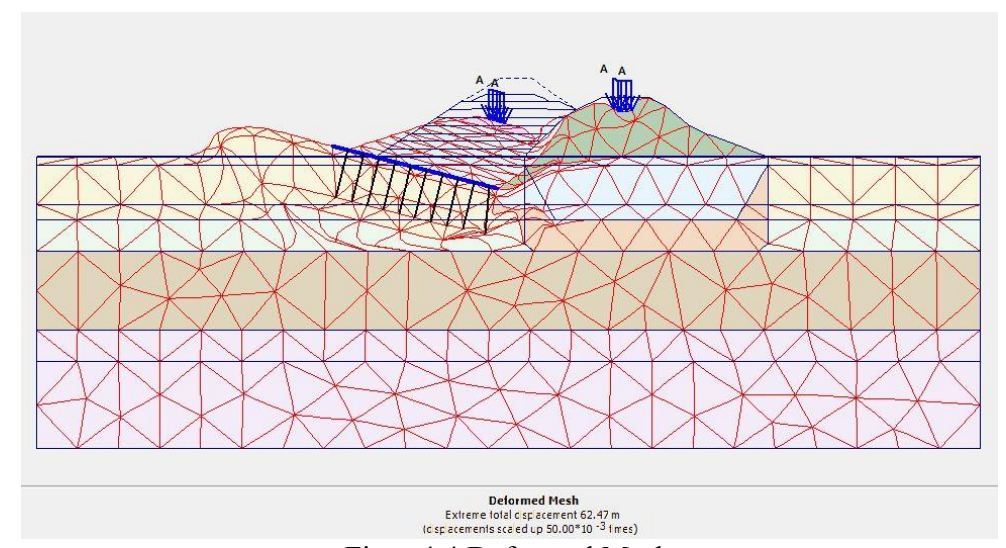

Figur 4.4 Deformed Mesh

Explanation of the image that changes the shape of the element that happens to show the reaction reaches $62.47 \mathrm{~m}$, this needs to be re-examined again for further planning.

Soft Soil Retrofitting Study with Bamboo Concave Mattress Against Stability of Jombang - Kertosono Railway Double Track Slope Due to Earthquake Load

Suprayitno, Helmy Darjanto 


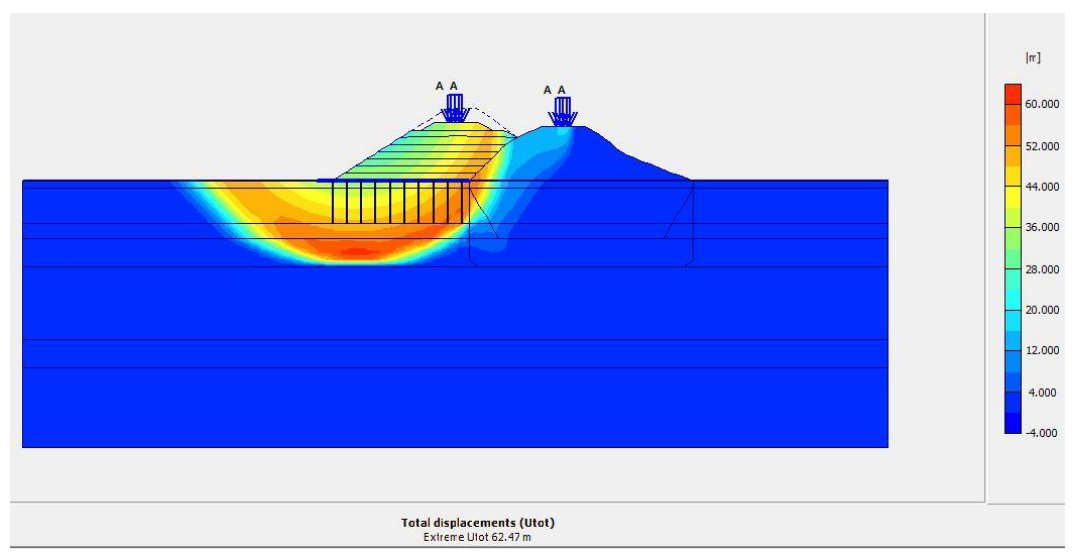

Figur 4.5 Total Displacement

From the image describes the displacement of elements that can occur in such a model has been made on areas of reach $62.47 \mathrm{~m}$ landslide or gelincir on the cover of the double line trains. In planning the need to look for the Safety factor that is safe, then we see on the graphs of SF that is happening.

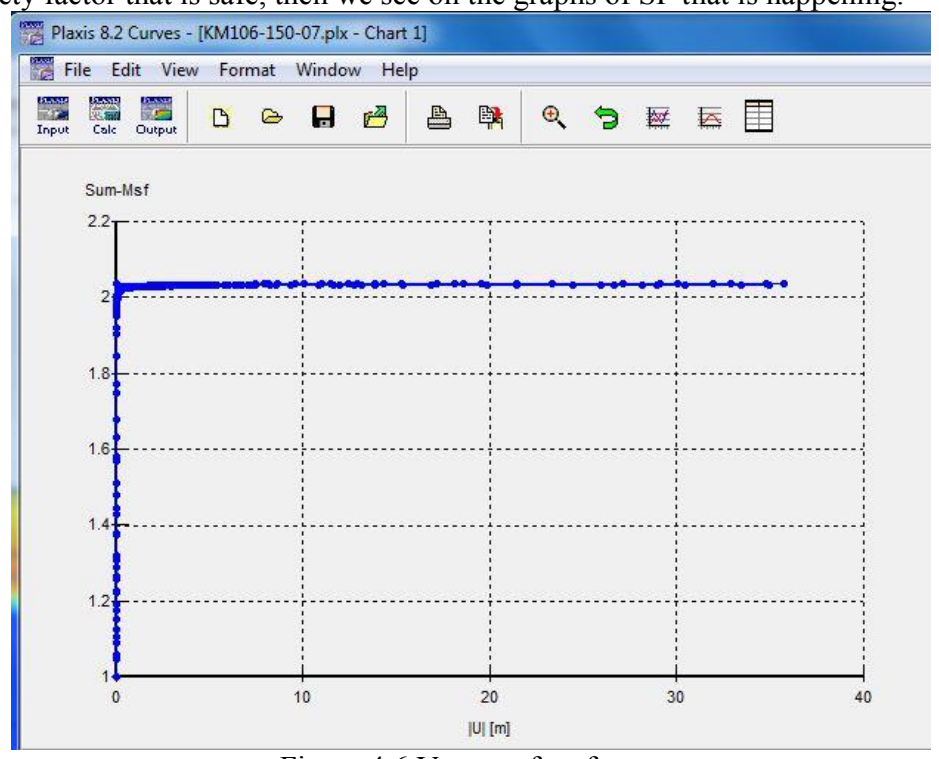

Figure 4.6 Vurva safety factor

In Figure 4.6 the SF 2.14 indicates the factor safet then the model is said to be safe in real executor with existing earthquake load or load of a train passing.

\section{CONCLUSIONS AND SUGGESTIONS}

1. That the stability of the soft soil can be improved by the method of cerucuk bamboo mats.

2. bamboo cerucuk mats That can strengthen the stability of the pile on the double track railway

3. That the brunt of the quake may affect the stability of the slopes of the double track railway pile

\section{REFERENCES}

DAS, Braja, m., (2002), Principles of Geotechnical Engineering. US: 5th Edition, Brooks/Cole.

Soft Soil Retrofitting Study with Bamboo Concave Mattress Against Stability of Jombang - Kertosono Railway Double Track Slope Due to Earthquake Load

Suprayitno, Helmy Darjanto 
Darjanto, h., report KJGJM-1 Package (2016), soft soil reinforcement purposes with bamboo cerucuk mats on the cover of the double track railway jombang Surabaya-kertosono,: September 2016

Idrus, m. a., (2014), Soil Investigation Report, Jakarta: PT Geoinves.

Nowak, a. Atkins, (2012), Design of New Earthworks, ICE Manuals, Volume II, Geotechnical Design, Construction, and Verification, BGA.

https://maps.google.co.id/, (2019), railroad Jombang Surabaya-Kertosono,.

Wesley., L.D. (1977), soil mechanics, prints to the VI. The Publisher's Public Works Agency, Jakarta: November 1977.

Jayanti, Oktalina, Winda (2016), analysis of Slope Stability and Foundation Against the pole and the 500 $\mathrm{kV}$ transmission lines: line Ungaran. Department Of Civil Engineering Geotechnical Engineering, Institut Teknologi Sepuluh Nopember Surabaya

Arya, I Wayan, (2002), the influence of the addition of the Cerucuk against the Strong increase in soft soil on the Modelling of shear in the laboratory. Department Of Civil Engineering Geotechnical Engineering, Institut Teknologi Sepuluh Nopember Surabaya 